\title{
Pengembangan Keprofesian Berkelanjutan dalam Meningkatkan Profesionalisme Guru Pendidikan Anak Usia Dini
}

\author{
Zakiya $^{1 凶}$, Nurhafizah $^{2}$ \\ Pendidikan Anak Usia Dini, Universitas Negeri Padang
}

\begin{abstract}
Abstrak
Pendidikan dan latihan Pengembangan Keprofesian Berkelanjutan (PKB) merupakan salah satu upaya Kementerian Pendidikan dan Kebudayaan melalui Direktorat Jenderal Guru Dan Tenaga Kependidikan dalam peningkatan kompetensinya. Tujuan penelitian ini yaitu mengetahui bagaimana pelaksanaan program PKB dalam meningatkan profesionalisme guru khususnya pada Pendidikan Anak Usia Dini (PAUD). Hasil penelitian bahwa melalui program $\mathrm{PKB}$, guru dapat memperbaiki nilai uji kompetensi guru (UKG) yang belum memenuhi kompetensi capaian minimal serta sebagai wadah pengembangan diri seorang pendidik agar menjadi lebih baik.
\end{abstract}

Kata Kunci : diklat PKB; meningkatkan profesionalisme; guru PAUD

\begin{abstract}
The Training on Continuing Professional Development is one of the efforts of the Ministry of Education and Culture through the Directorate General of teachers and education personnel in improving competency. The purpose of this study is to find out how the PKB program is implemented in raising teacher professionalism especially in Early Childhood Education (PAUD). The results of the study show that through the PKB program, teachers can improve the teacher competency test (UKG) value that has not met the minimum competency and as a place for self-development of an educator to be better.
\end{abstract}

Keywords: training PKB; increase profesionalism; PAUD teachers

Copyright (c) 2019 Lina Lina, Dadan Suryana, Nurhafizah

$\triangle$ Corresponding author :

Address : Padang, Sumatera Barat

Email : maiza1083@gmail.com

ISSN 2356-1327 (Media Cetak)

ISSN 2549-8959 (Media Online) 


\section{PENDAHULUAN}

Permasalahan mendasar bidang pendidikan salah satunya adalah perbaikan sumber daya manusia khusunya tenaga pendidik yang belum secara optimal dalam mengembangkan potensi-potensi yang dimilikinya. Perkembangan akan kebutuhan sumber daya manusia yang berkualitas akan terus ditingkatkan, karena hal ini amat sangat penting. Walaupun perkembangannya membutuhkan suatu proses yang secara perlahan namun pasti semakin meningkat dari tahun ke tahun. Konsep ini sejalan dengan perkembangan kemajuantantangan dunia kerja yang membutuhkan sumber daya manusia yang berkualitas, memilki daya saing, serta berorientasi untuk kebutuhan industri.

Sember daya pendidik memiliki kompetensi unggulan yang lebih memadai terutama dalam hal pengembangan kemampuan berpikir, kemampuan bertindak dan bersikap. Sejalan dengan kebutuhan tersebut, pembenahan pendidikan haruslah dilakukan. Pendidikan di abad ini di tuntut untuk bisa mengikuti perkembangan kemajuan zaman, pembaharuan disetiap bidang pendidikan yang modern dan profesional dengan berorientasi pendidikan.

Menurut (Direktorat Jendral guru dan Tenaga Kependidikan, 2018) Buku Panduan Pelaksanaan PKB tahun 2018 dijelaskan bahwa dalam semua lembaga pendidikan diharapkan harus mampu mewujudkan dan menciptakan peranannya secara efektif dengan keunggulan dalam kemimpinan, staf, pendidik, proses belajar mengajar, pengembangan pendidik dan tenaga kependidikan, kurikulum, iklim sekolah, dan keterlibatan orang tua dan masyarakat. Hal ini juga sesuai pendapat (Safitri, Hadiyanto, \& Ramli, 2018) beliau menjelaskan bahwa Keberhasilan penyelenggaraan pendidikan pada suatu lembaga pendidikan, hal ini ditentukan oleh keberhasilan pada proses pembelajaran yang dilakukan oleh guru, proses ini pembelajaran sangat penting dilakukan karena dalam rangka mencapai tujuan pembelajaran itu sendiri. Berhasil atau tidaknya proses belajar hal ini ditentukan oleh fungsi dan peran guru yaitu sejauh mana guru dapat menjalankan tugasnya secara profesional serta mampu dalam melaksanakan proses pembelajaran tersebut.

Guru merupakan suatu profesi yang sangat mempengaruhi hasil belajar anak didik. Menurut (Arianti, 2007) bahwa kemampuan seorang guru merupakan suatu gambaran yang hakikat dari prilaku guru atau tenaga kependidikan yang akan tampak sangat berarti dan berpengaruh terhadap lingkungan sekitarnya. Kemampuan guru atau tenaga oendidik ini juga merupakan suatu hal yang harus dimiliki dalam jenjang pendidikan karena kemampuan itu sangat penting dan harus di memiliki oleh guru, (Arianti, 2007) juga menjelaskan kemampuan guru antara lain; mampu mengembangkan sikap kepribadian, menguasai landasan pendidikan, menyusun bahan pengajaran yang lebih baik, melaksanakan proses program pengajaran sesuai prosedur, menilai hasil dan proses belajar yang telah dilaksanakan, menyelenggarakan program bimbingan pada setiap anak, menyelenggarakan administrasi sekolah, berinteraksi yang baik dengan teman sejawat dan masyarakat, dan aktif menyelenggarakan penelitian sederhana untuk kepentingan pengajaran sehingga mampu memecahkan masalah.

Salah satu upaya Direktorat Jenderal Guru dan Tenaga Kependidikan (Ditjen GTK) dalam mengembangkan program agar guru bisa meningkatkan kompetensinya yaitu dengan memfasilitasi 
dalam bentuk suatu program. Hasil Uji Kompetensi Guru (UKG) yang telah dilaksanakan pada tahun 2015 yang lalu telah dalam bentuk Program Guru Pembelajar dengan target pencapaian nilai rata-rata yaitu sebesar 65. Menurut data dari (Direktorat Jendral guru dan Tenaga Kependidikan, 2018) buku Pedoman Umum Pelaksaaan PKB jumlah guru yang telah mengikuti program ini tahun 2016 sebanyak 427.189 orang, atau $15,82 \%$ dari 2.699.516 orang guru. Kemudian partisipasi guru dalam Program Peningkatan Kompetensi Guru (PPG) dengan persentase sebesar $15,82 \%$ hal ini belum menggambarkan populasi guru secara keseluruhan, namun hal ini dapat memberikan masukan serta sekilas gambaran bahaimana hasil program yang diberikan kepada guru melalui PPG. Program tersebut dilanjutkan pada tahun 2017 dan 2018 dilakukan melalui Program Pengembangan Keprofesian Berkelanjutan yang disingkat dengan (PKB). Hal ini ditelusuri berdasarkan dari undang-undang pendidikan dan dokumen resmi otoritas pendidikan dalam Rencana Strategis (Renstra) pada Kementerian Pendidikan. PKB baru dikenal dalam UU Nomor 14 Tahun 2005 tentang Guru dan Dosen bahwa guru harus dibina dan dikembangkan. Pasal 32 menjelaskan, pembinaan dan pengembangan guru meliputi pembinaan dan pengembangan profesi dan karier.

Tabel 1. 1 Rata-rata Hasil UKG tahun 2015, 2016 dan 2017 untuk setiap jenjang pendidikan:

\begin{tabular}{l|c|l|l|l|l|l|l|l}
\hline \multirow{2}{*}{ Jenjang } & \multicolumn{3}{|c|}{ Jumlah Peserta } & \multirow{2}{*}{$\begin{array}{c}\text { Jml.Org. } \\
\text { Modul }\end{array}$} & \multicolumn{3}{|c|}{ Rerata UKG } & \multirow{2}{*}{$\%$} \\
\cline { 2 - 3 } & 2015 & 2016 & 2017 & $\mathbf{2 0 1 7}$ & 2015 & 2016 & 2017 & \\
\hline TK & 89 & 72 & 89 & 181 & 43,74 & 65,82 & 68,23 & 24,49 \\
\hline SD & 185 & 219 & 185 & 372 & 40,14 & 63,80 & 62,22 & 22,08 \\
\hline SMP & 65 & 85 & 65 & 131 & 44,16 & 65,33 & 67,76 & 23,61 \\
\hline SMA & 25 & 28 & 25 & 50 & 45,38 & 66,66 & 69,55 & 24,17 \\
\hline SMK & 12 & 19 & 12 & 20 & 44,31 & 70,30 & 68,53 & 24,22 \\
\hline SLB & 7 & 3 & 7 & 14 & 46,45 & 66,78 & 71,72 & 25,26 \\
\hline
\end{tabular}

Sumber Data: Dari Dirjen GTK

Berdasarkan tabel diaatas terlihat bahwa nilai rerata UKG pendidik TK pada tahun 2015 hingga 2017 terus mengalami peningkatan, artinya perbaikan nilai merupakan salah satu cara pengembangan diri pendidik dalam meningkatkan kompetensi sehingga menjadi guru profesional. Dengan hal ini jelas bahwa sangat penting sekali adanya kegiatan pengembangan guru salah satunya melalui kegiatan Diklat Pengembangan Keprofesian Berkelanjutan (PKB) ini. Sehingga guru-guru khususnya guru TK akan terus memperbaiki dan selalu memperbaharui pengetahuan tentang Pendidikan Anak Usia Dini.

\section{METODOLOGI}

Dalam tulisan ini merupakan penelitian kualitatif, sesuai objek kajian. Jenis penelitian ini dikategorikan dalam library research atau penelitian kepustakaan. Penelitian kepustakaan ini meliputi proses langkah demi langkah dalam mengumpulkan informasi berupa; catatan semua temuan mengenai profesionalisme guru secara umum pada setiap pembahasan penelitian yang didapat dalam literatur dan sumber-sumber terbaru, memadukan segala temuan baik teori atau berdasarkan observasi dilapangan, menganalisis segala temuan berdasarkan teori dan observasi, dan mengkritisi dan 
memberikan gagasan kritis dalam hasil penelitian terhadap wacana sebelumnya dengan menghadirkan wacana baru. Instrumen yang digunakan yaitu melalui perpustakaan, toko buku, pusat penelitian, pusat pelatiahan guru, jaringan internet dan mengakses info mengenai pelaksanaan PKB khususnya pendidik PAUD

\section{HASIL DAN PEMBAHASAN}

\section{Konsep Pengembangan dalam Keprofesian}

Pengembangan merupakan satu proses dalam meningkatkan keterampilan teknis, teoritis, konseptual dan moral melalui pendidikan dan pelatihan, hal ini dijelaskan menurut (Widodo, 2015). Selain itu Suparno juga menjelaskan bahwa pengembangan bagi guru dimaksudkan untuk merangsang atau memotvasi, memelihara, dan meningkatkan kualitas diri dalam memecahkan masalah-masalah keorganisasian.

Selanjutnya pengembangan guru berdasarkan kebutuhan institusi penting, namun yang lebih penting adalah berdasarkan pada kebutuhan individu seorang guru untuk bisa menjalani proses profesionalisme dalam peningkatan kinerja kerjanya. Karena substansi kajian dan konteks pembelajaran selalu berkembang dan berubah menurut dimensi ruang dan waktu, serta kemajuan teknologi makanya guru dituntut selalu meningkatkan kompetensinya.

Pengembangan adalah suatu upaya dalam melaksanakan berbagai pembinaan yang bertujuan untuk mengembangkan kualitas dan kuantitas pendidik agar tercapai tujuan dan sasaran yang ingin dicapai oleh guru, pihak sekolah dan masyarakat dengan melakukan berbagai cara seperti mengikuti seminar, workshop, dan pelatihan lainnya yang berkaitan dengan bidang tugas pendidik. Sekain itu pengembangan juga dilakukan dalam bentuk kecerdasan dalam menciptakan proses pembelajaran yang lebh baik, hal ini diperlukan kemampuan pengetahuan yang baik tentunya harus dimiliki oleh seorang guru agar tujuan pembelajaran tercapai dan kemampuan serta potensi peserta didik dapat berkembang maksimal (Nurhafizah, 2017). Selain itu pendidikan di sekolah menjadi tanggung jawab guru proses pendidikan seharusnya dapat menjadi bekal untuk diterapkan dalam kehidupan anak di lingkungan masyarakat (Nurhafizah, 2018).

Upaya-upaya yang dilakukan oleh seorang guru dalam meningkatkan profesionalismenya adalah dalam bentuk pengembangan diri.. Menurut buku pedoman umum Program Pengembangan Keprofesian Berkelanjutan (Direktorat Jendral guru dan Tenaga Kependidikan, 2018), bahwa pengembangan diri ini dimaksudkan suapya guru mampu mencapai atau meningkatkan kompetensinya. Kompetensi tersebut mencakup: kompetensi sosial, kompetensi kepribadian, kompetensi pedagogis dan kompetensi profesional, Sesuai diamanatkan yang ada didalam UndangUndang Sisdiknas Nomor 20 Tahun 2003.Seorang guru diharapkan mampumenjalankan tugas pokok sertakewajibannya dalam pembelajaran dan membimbingan peserta didik, termasuk pula dalam hal melaksanakan tugas tambahan yang sesuai dan relevan dengan fungsi sekolah secara profesional.

Berbagai bentuk kegiatan pengembangan diri tersebut dapat dilakukan dengan mengikuti program pendidikan dan pelatihan (diklat) fungsional serta mengikuti kegiatan kolektif guru sesuai daerah masing. Program Diklat fungsional merupakan kegiatan guru dalam mengikuti pelatihan 
atau pendidikan dengan tujuan untuk mencapai standar kompetensi profesi yang profesional dalam meningkatkan keprofesian guru untuk memiliki kompetensi di atas rata-rata standar kompetensi profesi guru. Maka dari itu, tahun 2018 Direktorat jendral GTK mengembangkan suatu Program Pengembangan Keprofesian Berkelanjutan (PKB) melalui suatu kegiatan Pendidikan dan Pelatihan Guru dengan tujuan yang paling utama yaitu untuk meningkatkan kompetensi guru.

\section{Profesionalisme Guru}

Menurut Kunandar, dalam (Partiningsih, 2003) menjelaskan bahwa profesional adalah suatu pekerjaan atau kegiatan yang dilakukan oleh seseorang sesuai dengan pendidikan profesi (Indonesia, 2005) Tenaga pendidik atau guru adalah pendidik yang profesional dengan tugas utama mendidik, mengajar, membimbing, mengarahkan, melatih, menilai, serta mengevaluasi peserta didik pada jalur pendidikan anak usia dini atau pendidikan formal, pendidikan dasar serta pendidikan menengah. Profesionalismenya seorang guru merupakan perbaikan kondisi pendidikan kearah, nilai, tujuan dan kualitas yang lebih bermutu. Profesionlisme yang dimaksud juga suatu keahlian dan wewenang dalam bidang pendidikan dan pengajaran yang berkaitan dengan pekerjaan seseorang yang menjadi mata pencaharian.

Menurut (Yusutria, 2017) penelitiannya tentang profesionalisme guru dalam meningkatkan kualitas sumberdaya manusia bahwa guru yang profesional itu mencerminkan pada keberhasilan nya dalam melaksanaan tugas mengajarnya yang ditandai dengan kemampuannya baik dalam menguasai materi secara teori ataupun prakteknya. Meningkatkan kualitas SDM dilakukan dengan jalur kualifikasi, kompetensi dan sertifikasi pendidik.

Selain itu (Yusutria, 2017) menjelaskan bahwa guru profesional bisa dipengaruhi oleh : a) jenjang pendidikan atau kualifikasi pendidikan b) keikut sertaanya dalam berbagai kegiatan pengembangan diri misalnya mengikuti pelatihan, penyetaraan, workshop serta berbagai penataran yang telah diikuti sesuai bidangnya, c) mampu membangun hubungan interaksi yang baik dan luas pada semua lapisan masyarakat pada umumnya, d) mampu mengembangkan etos kerja atau peningkatan kinerja yang mengutamakan pelayanan prima dan bermutu tinggi dalam bidang pendidikan, e) mengadopsi dan mengembangkan dalam memanfaatkan teknologi dan komunikasi.

Selain itu, mengutip perjelasan dari (Hadiyanto, 2004) beliau menjelaskan bahwa keberadaan guru di Indonesia ini sebaiknya dan seharusnya mampu memainkan peran yang ideal. Peran yang ideal tersebut antara lain: berkualifikasi pendidikan guru harus lebih memadai, mempunyai visi dan misi sebagai yang jelas, uru harus mampu menstransferkan ilmunya yang dimilikinya kepada peserta didiknya, mampu dan bisa memperbaiki sikap atau memberi memotivasi kepada peserta didik agar lebih semangat dalam mengikuti proses pembelajaran, mengajar sesuai dengan bidang kompetensi ysng dimilikinya, mampu menguasai kelas, dan menciptakan suasana kelas yang nyaman dan menyenangkan bagi anak, menguasai materi pelajaran, mampu menggunakan berbagai metode pembelajaran yang bervariasi, berwawasan dan pengetahuan yang luas, mampu berkomunikasi dengan baik bahasa baku, santun, suara logat dan ekspresi yang tepat dan tidak keras, menjadi human relation yang tepat baik, berbadan sehat jasmani dan rohani, bermoral dan berakhlak mulia, berbudi 
pekerti yang luhur, Memiliki rasa bertanggungjawab, selalu disiplin dan tepat waktu, berdedikasi tinggi, berwibawa, berjiwa besar, berjiwa sosial, jujur, adi, arif bijaksana, dapat dipercaya, percaya diri, , tegas, rabar dan penyayang, ramah, memiliki Kreatifitas, selalu berinovasi, mandiri, demokratis, humoris, disenangi peserta didik perikemanusiaan, mampu bekerja sama dengan baik, mempunyai prakasa, berpenampilan menarik pakaian rapi rambut make up serta gerak-gerik dan bisa menjadi suri teladan bagi peserta didik dan masyarakat.

\section{Peranan Guru dalam Pendidikan Anak Usia Dini}

Dalam proses belajar mengajar Peran guru amat sangat banyak. Berikut ini dikemukan peranan guru dijelaskan menurut pendapat (Prawoto 1981:21) beliau menjelaskan bahwa : a). Peran guru sebagai pembimbing. Peran guru sebagai pembimbing ini lebih diutamakan, karena kehadiran guru disekolah tersebut merupakan kehadirannya untuk membimbing peserta didik menjadi manusia cakap, dewasa dan mempunyai sikap yang arif. Tanpa bimbingan seorang guru, tentunya peserta didik akan mengalami berbagai kesulitan dalam menghadapi perkembangan dan perubahan dirinya. kelemahan peserta didik menyebabkan lebih banyak tergantung pada bantuan guru. Tetapi dengan beriringnya waktu peserta didik akan mampu menjadi pribadi yang lebih mandiri tentunya dalam pengawasan guru. b). Guru sebagai Fasilitator. Peran Guru sebagai fasilitator ini hendaknya memberikan fasilitas yang dapat memungkinkan dan memberi kemudahan kepada peserta didiknya dalam belajar. Menciptakanlingkungan belajar yang menyenangkan, jika suasana ruang kelas yang pengap, meja dan kursi yang berantakan tentunya membuat anak malas dalam belajar dan tidak konsentrsi dalam mengikuti pembelajaran. c). Peran guru sebagai mediator. Guru sebagai mediator ini hendaknya memiliki pengetahuan dan pemahaman yang baik tentunya tentang media pendidikan dalam berbagai bentuk, sumber dan jenisnya, baik media nonmaterial atau materil. Media berfugsi sebagai alat bantu komunikasi yang berguna untuk mengefektifkan proses interaksi edukatif. Keterampilan dan kemampuan dalam menggunakan semua media tersbut diharapkan media tersebut digunakan oleh guru tentunya disesuaikan dengan pencapaian tujuan pembelajaran. Sebagai itu, guru sebagai mediator, dapat diartikan sebagai penengah dalam proses belajar peserta didik. Jika dalam metode diskusi, peranan guru yaitu sebagai penengah, atau sebagai pengatur jalannya proses kegiatan diskusi. d). Peranan guru sebagai motivator. Guru Sebagai motifator ini hendaknya guru lebih bisamemoifasi anak didik agar lebih bersemangat dan aktif dalam mengikuti pembelajaran.

Peranan guru selain mendidik dan mengajarkan tentang pembelajaran upaya lainya yang garu harus dimiliki guru yaitu harus mampu memberikan motivasi. Guru harus dapat menganalisis segala macam bentuk yang melatarbelakangi peserta didiktidak mau belajarataupun menurun prestasinya dalam pembelajaran. Selain itu Peranan guru yaitu sebagai sentral dalam berbagai kegiatan interaksi belajar mengajar. Namun demikian peran guru tidak boleh terlalu dominan, (Dwirahman, 2013) menyatakan peran guru masih sangat dominan sebagai pengajar. Peran ini perlu dikurangi dengan lebih menonjolkan peran sebagai fasilitator. 
Menurut (Mulyasa, 2005) beliau juga menjelaskan bahwa peran guru adalah guru sebagai pendidik, guru pengajar, guru pembimbing, guru sebagai pelatih, guru sebagai penasihat, guru sebagai pembaharu (inovator), model dan teladan, pribadi, peneliti, pendorong kreativitas, pembangkit pandangan, pekerja rutin, pembawa cerita, aktor, emansipator, evaluator, pengawet serta guru sebagai kulminator.

Sesuai dengan pendapat diatas maka kita dapat mengetahui bahwa aspek peranan dinamis bagi seorang guru merupakan perilaku dan tindakan yang dilaksanakan oleh orang yang menempati jabatan atau kedudukan dan melaksanakan hak dan kewajibannya tersebut sesuai dengan kedudukannya. Di dalam berbagai elemen masyarakat dari yang terbelakang sampai yang paling maju, peranan guru amat sangat penting terutama dalam dunia pendidikan. Oleh karena itu hampir peran guru merupakan satu yang dijadikan tauladan oleh masyarakat. Dalam proses belajar mengajar atau pendidikan secara keseluruhan.

Pekerjaan seorang guru merupakan salah satu bidang pekerjaan yang terkait langsung dengan kebutuhan masyarakat, khususnya bodang pendidikan. Oleh karena itu mayarakat akan bisa mengamati dan menilai keberhasilan dan kegagalan seorang guru dengan lebih teliti dan kritis. Tugas seorang guru adalah sesuatu yang lumrah berbagai upaya peningkatan mutu pendidikan nasional harus terus ditingkatkan (Masluyah, n.d.). Selain itu peran guru merupakan salah satu faktor penentu keberhasilan atau kegagalan. Maka daro itu pentingnya berbagi upayaupaya dalam peningkatan mutu dan inovasi pendidikan di tingkat sekolah (fullan, 1992). Terlebih lagi saat ini masyarakat utamanya para orang tua mempunyai peran yang sangat penting dengan kebrhasilan dalam layanan pendidikan yang berkualitas dan sebagian besar tanggung jawab terdepan untuk mewujudkan harapan dan cita-cita tersebut memang berada di pundak guru.

Peran guru amat sangat penting hal ini dibahas oleh (Gaffar 1998:4) dalam jurnal mimbar pendidikan, beliau menjelaskanbahwa guru memegang peranan strategis yang terutama yaitu dalam usahamembentuk watak bangsa melalui pengembangan niali kepribadian dan nilai-nilai lain yang diinginkan. Berdasarkan dimensi tersebut peran guru sangat sulit digantikan oleh orang lain. Jika dipandang dari dimensi pembelajaran peran seorang guru dalam masyarakat Indonesia, tetap lah menjadi hal yang paling dominan, sekalipun teknologi juga dapat dapat dimanfaatkan dalam membantu proses pembelajaran, yang kita ketahui bahwa berkembangnya terknologi amat cepat. Perkembangan ini disebabkan oleh karena adanya dimensi proses pendidikan atau lebih khusus lagi bahwa proses pembelajaran yang diperankan oleh seorang guru yang tidak dapat digantikan oleh teknologi.

Dalam Peraturan Pemerintah (PP) No 19 tahun 2005 pasal 8 ayat 3 disitu dijelaskan bahwa kompetensi yang dimiliki guru sebagai agen perubahan dan pembelajaran pada jenjang pendidikan dasar dan menengah serta pendidikan anak usia dini hal ini meliputi kompetensi pedagogik, kompetensi kepribadian, kompetensi profesional dan kompetensi sosial.(Republik Indonesia, 2005) Standar kompetensi guru ini dikembangkan secara utuh dari empat kompetensi utama. Keempat kompetensi tersebut terintegrasi dalam kinerja guru mengacu pada Peraturan Menteri Pendidikan Nasional nomor 16 tahun 2007 standar kompetensi guru mencakup kompetensi guru inti dan dikembangkan menjadi kompetensi guru 
pada

masing-masing

satuan

pendidikan.(Pendidikan Nasional, 2007)

\section{Upaya yang Dilakukan dalam Meningkatkan Profesionalisme Guru}

Tugas guru di masa depan tanpa kita sadari, akan semakin sulit dan berat. Menurut (Thoifuri, 2013) menjelaskna bahwa menghadapi hidup mulai dari abad ke-21 ini sampai sekarang yang mensyaratkan adanya profesionalisme dalam meraih peluang kerja. Kemudian menuntut seoraang untuk guru tidak hanya mempunyai persyaratan secara formal akademis saja misalnya yang berupa ijazah atas sertifikat saja akan tetapi berkompeten dan memiliki keterampilan mengajar yang baik serta mengikuti dapat mengikuti perkembangan ilmu pengetahuan yang terus bertambah dan mengalami perubahan. Tugas guru bukan hanya mentransfer ilmu pengetahuan, keterampilan dan teknologi yang dimilikinya kepada peserta didiknya, akan tetapi gurupun juga harus mengemban tugas yang dibebankan masyarakat kepadanya. Tugas yang dimaksudkan tersebut meliputi mengajarkan kebudayaan dalam arti yang luas, keterampilan dalam menjalani hidup (life skills), dan nilai. Tugas yang demikian berat ini, sudah selayaknya bila kemampuan profesional guru juga terus ditingkatkan agar guru mampu menjalankan tugasnya dengan baik. Sehubungan dengan hal itu bahwa guru itu sendiri harus mau dan bisa membuat penilaian atas kinerjanya sendiri dan mau melakukan evaluasi diri sebagai bentuk langkah awal dalam memperbaiki kinerja dirinya. Di samping seorang guru harus pula lebih memperhatikan berbagai pendapat dan harapan masyarakat luas.

Kemudian selain itu profesionalisme seorang pendidik juga perlu didukung dengan kompetensi dan hal ini harus atau wajib dimiliki oleh guru. Kompetensi ini mencakup 4 aspek sebagai berikut menurut E mulyasa dalam dalam (Ranaklince, 2016) prosiding temu ilmiah nasional guru (Ting) VIII menjelaskan bahwa:

\section{Kompetensi pedagogik}

Dalam standar nasional pendidikan Sisdiknas) penjelasan pasal 28 ayat 3 butir a dimaksud pada pasal tersebut bahwa kompetensi pedagogik merupakan kemampuan seorang guru dalam mengelola kegiatan pembelajaran, memahami peserta didik yang meliputi pemahaman terhadap karateristik peserta didik, merancangan dan melaksanakan pembelajaran, serta melakukan evaluasi hasil belajar mengajarkemudian melakukan pengembangan peserta didik untuk mengaktualisasikan berbagai potensi yang dimiliki peserta didik.

\section{Kompetensi kepribadian}

Dalam standar nasional pendidikan (Sisdiknas) menjelaskandari pasal 28 ayat 3 butir b di kemukakan bahwa kompetensi kepribadian merupakan kemampuan kepribadian diri seorang guru yang mantap, stabil, dewasa Arif bijaksana, berwibawa, berakhlak mulia, dan menjadi teladan bagi peserta didik dan masyarakat sekitar.

\section{Kompetensi profesional}

Dalam standar nasional pendidikan (Sisdiknas) pasal 28 ayat 3 butir c telah dikemukakan penjelasan bahwa yang dimaksud dengan kompetensi profesional yaitu kemampuan seorang guru dalam menguasai materi pembelajaran secara dalam dan luas serta mampu menunjukkan sikap yang profesional dalam membimbing peserta didik tentunya memenuhi standar kompetensi yang diterapkan dalam standar nasional pendidikan. (Indonesia, 2003) 


\section{Kompetensi sosial}

Dalam Standar nasional pendidikan (Sisdiknas) penjelasan pasal 28 ayat 3 butir d dikemukakan bahwa pengertian dari Kompetensi sosial maksudnya adalah kemampuan seorang guru sebagai bagian dari masyarakat dalam berkomunikasi serta bergaul secara baik dan efektif dengan anak didik, sesama pendidik dan dengan tenaga kependidikan orang tua wali murid dan masyarakat sekitarnya.

Beberapa upaya di tentunya tidak akan dapat dilakukan dengan baikjika tidak dilakukan dengan upaya kegiatan yang nyatauntuk menjadikan guru benar-benar profesional di bidangnya serta memperhatikan segala aspek pelayanan yang dibutuhkan oleh guru.

\section{Pola Pelaksanaan Diklat PKB}

Pelaksanaan program diklat guru TK ini, dilaksanakan dengan menggunakan beberapa metode yaitu dengan moda tatap muka In On In atau Tatap muka Penuh. Pelaksanaannya dilakukan pada tingkat di tingkat kabupaten/kota, provinsi, maupun nasional. Moda tatap muka merupakan bagian dari sistem pembelajaran diharapkan terjadi interaksi secara langsung antara fasilitator dengan peserta diklat pembelajaran. Interaksi komunikasi dalam pembelajaran yang terjadi dalam tatap muka meliputi pemberian input materi sesuai modul, diskusi tanya jawab, latihan, kuis, praktik langsung, dan tugas mandiri. Moda tatap muka menurut (Direktorat Jendral guru dan Tenaga Kependidikan, 2018) dalam juknis Pedoman Pelaksanaan PKB yaitu pelaksanaannya dilakukan dengan dua alternatif, yaitu: 1) Tatap muka penuh (6 hari), 2) Tatap muka In On In dan belajar mandiri.

Pelaksanaan Diklat PKB dengan pola tatap muka penuh merupakan kegiatan pelatihan dengan alokasi waktu pembelajarannya dilakukansecara tatap muka antara peserta dan fasilitator atau Instruktur nasional. Pada pola tatap muka penuh ini, jumlah jam pelajaran yang diikuti peserta yaitu 60 jp bagi guru mata pelajaran, Guru Taman Kanak-Kanak (TK), Guru PLB, Guru kelas SD, dan Guru BKdalam menyelesaikan materi tentang kompetensi Pedagogik dan profesional dalam sesuai modul yang di laksanakan.

Pelaksanaan diklat PKB dengan pola tatap muka In On In dan belajar mandiri adalah kegiatan pembelajran dan pelatihan yang dilakukan sebagian sebagian sebagian tatap muka dan sebagian dilakukan dengan belajar mandiri. Kegiatan dengan pola tatap muka ini di awal kegiatan diberi istilah In On In atau in service learning 1 atau in-1 atau tatap muka pertama, sementara kegiatan tatap muka di akhir kegiatan diberi istilah In Service Learning 2 atau In-2. Kegiatan dengan istilah On artinya On the Job Learning (On) adalah pola kegiatan belajar dengan mandiri yang merupakan kelanjutan dari proses kegiatan In-1 dan kegiatan on ini peserta Diklat diberikan tugas agar bisa dikerjakan dimana saja, tanpa meninggalkan tugas mengajar.

Sesuai dengan (Direktorat Jendral guru dan Tenaga Kependidikan, 2018) Pedoman Umum Pelaksaan Program Diklat PKB tahun 2018, pelaksanaan program Diklat PKB ini dengan pola tatap muka In On In dan belajar mandiriuntuk seorangGuru TK, Guru PLB, Guru Kelas SD, Guru Mapel dan Guru BK Kegiatan pembelajaran ini terdiri atas kegiatan In-1, kegiatan On, dan kegiatan In-2, dengan pola 20JP-20JP-20JP (20-20-20) atau 20JP-30JP10JP (20-30-10). 


\section{KESIMPULAN}

Diklat PKB sangat bermanfaat bagi guru dalam pengembangan dan memperbaiki kualitas diri, pembaharuan pengetahuan pendidikan khususnya PAUD serta sebagai upaya untuk meningkatkan prestasi, kinerja serja lebih profesional dalam bidangnya. Pemerintah dan pihak terkait tidak hanya sebatas penyediaan informasi tetapi ikut terlibat sebagai fasilitator penyelenggara kegiatan agar secara nyata kegiatan ini dapat terlaksana dengan baik. Pemerintah bekerjasama dengan forum resmi di ikatan PAUD bersama-sama menyukseskan program ini dengan sebaik-baiknya.

\section{UCAPAN TERIMA KASIH}

Penulis ucapkan terimakasih kepada semua pihak yang telah membantu penulis terutama kepada pembimbing ibu Dr. Nurhafizah, M.Pd yang sudah membantu peneliti dalam menyempurnakan hasil penelitian ini. Ucapan terimaksih juga disampaikan kepada tim editor Jurnal Obsesi yang telah memberikan saran, kritik dan rekomendasi untuk perbaikan.

\section{DAFTAR PUSTAKA}

Arianti, S. (2007). Bahan Ajar Profesi Kependidikan. Program Studi Pendidikan Sejarah Fakultas Keguruan dan Ilmu Pendidikan Universitas PGRI Palangka Raya.

Direktorat Jendral guru dan Tenaga Kependidikan, K. P. N. (2018). Melalui Pendidikan dan Pelatihan Guru. Jakarta.

Dwirahman, E. (2013). Peningkatan Kreativitas Melalui Pendekatan Inquiri dalam Pembelajaran Sains. Jurnal Pendidikan Usia Dini, 7(2), 240-250. Retrieved from http://journal.unj.ac.id/unj/index.php/jp ud/article/view/3873

Hadiyanto. (2004). Mencari Sosok Disentralisasi Manajemen Pendidikan Di Indonesia. 206.
Indonesia, R. (2003). Undang-Undang Nomor 20 Tahun 2003 Sistem Pendidikan Nasional. Jakarta.

Indonesia, R. (2005). Undang-Undang Republik Indonesia Nomor 14 Tahun 2005 Tentang Guru dan Dosen.

Masluyah, S. (n.d.). Sistem Prajabatan Guru Profesional di Indonesia.

Mulyasa. (2005). Menjadi guru profesional menciptakan pembelajaran kreatif dan menyenangkan. Bandung Remaja Rosdakarya, 24-29.

Nurhafizah. (2017). PEDAGOGI: Jurnal Anak Usia Dini dan Pendidikan Anak Usia Dini. 3, 103-115.

Nurhafizah, N. (2018). Bimbingan Awal Kewirausahaan pada Anak Usia Dini. Jurnal Konseling Dan Pendidikan, 6(2), 62-67. https://doi.org/10.29210/127300

Partiningsih. (2003). Pelatihan dan Pengembangan Profesionalisme Guru di MAN 2 Bandar Lampung.

Pendidikan Nasional, M. (2007). Peraturan Menteri Pendidikan Nasional Nomor 16 Tahun 2007 tentang Standar Kualifikasi Akademik dan Kompetensi Guru (pp. 1-32). pp. 1-32.

Ranaklince. (2016). Strategi Peningkatan Profesionalisme Guru Dalam Menghadapi Tantangan Di Era Digital. Prosiding Temu Ilmiah Nasional Guru (Ting), (November), 164-179.

Republik Indonesia, P. (2005). Peraturan Pemerintah Republik Indonesia Nomor 19 Tahun 2005 tentang Standar Nasional Pendidikan (pp. 1-71). pp. 171.

Safitri, A., Hadiyanto, \& Ramli, E. (2018). Persepsi Guru tentang Proses Supervisi Akademik Kepala SMA N 1 Kecamatan Kapur IX Kabupaten Lima Puluh Kota. Jurnal Bahana Manajemen Pendidikan, 7(1).

Thoifuri. (2013). Menjadi Guru Inisiator. februari 2013.

Widodo, S. E. (2015). Manajemen Pengembangan Sumber Daya Manusia. Pustaka Belajar.

Yusutria. (2017). ProfesionalimeGuru Dalam. Meningkatkan Kualitas Sumber Daya Manusia. Jurnal Curricula, 2. 